\title{
Influence of Consciousness Energy Healing Treatment on the Isotopic Abundance Ratio of Sulfamethoxazole Using LC-MS and GC-MS Spectrometry
}

\author{
Alice Branton ${ }^{1}$, Mahendra Kumar Trivedii ${ }^{1}$, Dahryn Trivedi ${ }^{1}$ and Snehasis Jana ${ }^{2 *}$ \\ ${ }^{1}$ Trivedi Global, Inc., Henderson, Nevada, USA \\ ${ }^{2}$ Trivedi Science Research Laboratory Pvt. Ltd., India
}

Submission: December 04, 2020; Published: January 20, 2021

*Corresponding author: Snehasis Jana, Trivedi Science Research Laboratory Pvt. Ltd., Thane-West, Maharashtra, India

\begin{abstract}
Sulfamethoxazole is a broad spectrum antibiotic especially used for the treatment of infections caused by bacteria. This study was performed to investigate the impact of The Trivedi Effect ${ }^{\circledR}$-Biofield Energy Healing Treatment on the structural properties and the isotopic abundance ratio of sulfamethoxazole using LC-MS and GC-MS spectroscopy. Sulfamethoxazole sample was divided into two parts, one part of sulfamethoxazole was considered as control (no Biofield Energy Treatment was provided), while the second part was treated with The Trivedi Effect $(\circledR$-Consciousness Energy Healing Treatment remotely by a renowned Biofield Energy Healer, Alice Branton and termed as a treated sample. The LC-MS spectra of both the samples at retention time (R) 2.5 minutes exhibited the mass of the deprotonated molecular ion peak at $m / z 252$ [M-H] (calculated for $\mathrm{C}_{10} \mathrm{H}_{10} \mathrm{~N}_{3} \mathrm{O}_{3} \mathrm{~S}$, 252.04). The LC-MS based isotopic abundance ratio of $\mathrm{P}_{\mathrm{M}+1} / \mathrm{P}_{\mathrm{M}}$ in the treated sulfamethoxazole was significantly increased by $44.67 \%$ compared with the control sample. Thus, ${ }^{13} \mathrm{C},{ }^{2} \mathrm{H},{ }^{15} \mathrm{~N},{ }^{17} \mathrm{O}$, and ${ }^{33} \mathrm{~S}$ contributions from $\left(\mathrm{C}_{10} \mathrm{H}_{10} \mathrm{~N}_{3} \mathrm{O}_{3} \mathrm{~S}\right)$ - to $\mathrm{m} / \mathrm{z} 253$ in the treated sample were significantly increased compared with the control sample. The control and treated sulfamethoxazole showed the presence of a chromatographic peak at the retention time of $16.91 \mathrm{~min}$ in the GC-MS chromatograms. The peak area $\%$ of the treated sample was significantly increased by $80.3 \%$ compared to the control sample.
\end{abstract}

The GC-MS based isotopic abundance ratio of $\mathrm{P}_{\mathrm{M}+1} / \mathrm{P}_{\mathrm{M}}$ and $\mathrm{P}_{\mathrm{M}+2} / \mathrm{P}_{\mathrm{M}}$ in the treated sulfamethoxazole was significantly increased by $24.13 \%$ and $90.53 \%$, respectively compared with the control sample. Hence, ${ }^{13} \mathrm{C},{ }^{2} \mathrm{H},{ }^{15} \mathrm{~N},{ }^{17} \mathrm{O},{ }^{18} \mathrm{O},{ }^{33} \mathrm{~S}$, and ${ }^{34} \mathrm{~S}$ contributions from $\left(\mathrm{C}_{10} \mathrm{H}_{10} \mathrm{~N}_{3} \mathrm{O}_{3} \mathrm{~S}\right)^{+}$to $\mathrm{m} / \mathrm{z} 254$ and 255 in the Biofield Energy Treated sample were significantly increased compared with the control sample. The isotopic abundance ratios of $\mathrm{P}_{\mathrm{M}+2} /$ $\mathrm{P}_{\mathrm{M}}\left({ }^{2} \mathrm{H} /{ }^{1} \mathrm{H}\right.$ or ${ }^{13} \mathrm{C} /{ }^{12} \mathrm{C}$ or ${ }^{15} \mathrm{~N} /{ }^{14} \mathrm{~N}$ or ${ }^{17} \mathrm{O} /{ }^{16} \mathrm{O}$ or $\left.{ }^{33} \mathrm{~S} /{ }^{32} \mathrm{~S}\right)$ and $\mathrm{P}_{\mathrm{M}+2} / \mathrm{P}_{\mathrm{M}}\left({ }^{18} \mathrm{O} /{ }^{16} \mathrm{O}\right.$ or $\left.{ }^{34} \mathrm{~S} /{ }^{32} \mathrm{~S}\right)$ in the treated sulfamethoxazole were significantly altered compared to the control sample. It can be assumed that the changes in isotopic abundance and mass peak intensities could be due to changes in nuclei possibly through the interference of neutrino particles via The Trivedi Effect ${ }^{\circledR}$ - Consciousness Energy Healing Treatment. The new form of sulfamethoxazole would be better designing novel pharmaceutical formulations that might offer better solubility, dissolution, absorption, bioavailability and therapeutic response against urinary tract infections, ear infections, tuberculosis, traveler's diarrhea, shigellosis, bronchitis, and pneumocystis jiroveci pneumonia, etc.

Keywords: Sulfamethoxazole; The Trivedi Effect ${ }^{\circledR}$; Biofield Energy; Consciousness Energy Healing Treatment; LC-MS; GC-MS

\section{Introduction}

Sulfamethoxazole is a broad spectrum antibiotic especially used for the treatment of infections caused by bacteria. It acts as a bacteriostatic antibacterial agent, which inhibits the bacterial synthesis of dihydrofolic acid by competing with para-aminobenzoic acid (PABA) for binding to dihydropteroate synthetase. Finally, by this mechanism sulfamethoxazole inhibits bacterial nucleotides and DNA synthesis [1,2]. Sulfamethoxazole was used in combination with the trimethoprim to treat urinary tract infections, tuberculosis, traveler's diarrhea, ear infections, bronchitis, shigellosis, and Pneumocystis jiroveci pneumonia [3]. However, some common adverse effects associated with the sulfamethoxazole treatment are nausea, vomiting, loss of appetite, and skin rashes. Sulfamethoxazole is rapidly absorbed orally while it is also well-absorbed topically. The free forms of sulfamethoxazole are considered to be the therapeutically active forms. Approximately $70 \%$ of sulfamethoxazole are bound to 
plasma proteins. Bioavailability and stability profile of any drug depends upon its physicochemical profile [4,5]. Further, physicochemical properties have important role in different pharmaceutical compounds such as in its dissolution, absorption, and bioavailability profile, which have direct influence to achieve maximum biological activities [6,7].

In this scenario, it was observed that Biofield Energy Healing Treatment (The Trivedi Effect ${ }^{\circledR}$ ) has the considerable impact on various properties such as particle size, surface area, and other chemical and thermal behaviour of pharmaceutical/nutraceutical [8-10]. The Trivedi Effect ${ }^{\circledR}$ is a natural and only scientifically proven phenomenon in which a person can harness this inherently intelligent energy and transmit it anywhere on the planet through the possible mediation of neutrinos [11]. "Biofield Energy" the electromagnetic energy field which exists surrounding the living beings, which can transmit the electromagnetic energy in the form of bio-photons, generated by the continuous movement of the electrically charged particles like ions, cells, etc. inside the body. Biofield Energy Healing specialists have the ability to harness the energy from the environment or the "Universal Energy Field" and can transmit into any living and non-living object(s), this process is called Biofield Energy Healing Treatment $[12,13]$. Biofield based Energy Therapies have been reported to with significant outcomes against various disease [14]. National Center of Complementary and Integrative Health $(\mathrm{NCCIH})$ has recognized and accepted Biofield Energy Healing as a Complementary and Alternative Medicine (CAM) health care approach along with the other therapies, medicines, and practices such as yoga, Qi Gong, Tai Chi, hypnotherapy, Reiki, etc. [15].

These therapies have been accepted by most of the U.S.A. population with several advantages [16]. The Trivedi Effect ${ }^{\circledR}$ Consciousness Energy Healing Treatment has been widely reported with astounding capability to alter the characteristic properties of the several non-living materials and living object(s), i.e., organic compounds $[17,18]$, metals and ceramic $[19,20]$, crops [21,22], microbes [23,24], etc. The Consciousness Energy Healing Treatment has also enhanced the bioavailability $[25,26]$ and isotopic abundance ratio $[27,28]$ of the pharmaceutical compounds. The stable isotope ratio analysis has various applications in different scientific fields for understanding the isotope effects resulting from the variation of the isotopic composition of the molecule [29,30]. Isotope ratio analysis can be performed by using the conventional mass spectrometry (MS) techniques such as gas chromatography - mass spectrometry (GCMS) and liquid chromatography - mass spectrometry (LC-MS) in low micro molar concentration with sufficient precision [30,31]. The Trivedi Effect ${ }^{\circledR}$-Biofield Energy Healing Treatment could be an economical approach for designing better pharmaceuticals formulations. Therefore, in this study, special attention was taken to improve the physicochemical parameters of the pharmaceutical product, e.g., sulfamethoxazole. Hence, LC-MS and GC-MS were used in this study to characterize the structural properties and evaluate the isotopic abundance ratio analysis of $\mathrm{P}_{\mathrm{M}+1} / \mathrm{P}_{\mathrm{M}}\left({ }^{2} \mathrm{H} /{ }^{1} \mathrm{H}\right.$ or ${ }^{13} \mathrm{C} /{ }^{12} \mathrm{C}$ or ${ }^{15} \mathrm{~N} /{ }^{14} \mathrm{~N}$ or ${ }^{17} \mathrm{O} /{ }^{16} \mathrm{O}$ or ${ }^{33} \mathrm{~S} /{ }^{32} \mathrm{~S}$ ) and $\mathrm{P}_{\mathrm{M}+2} / \mathrm{P}_{\mathrm{M}}\left({ }^{18} \mathrm{O} /{ }^{16} \mathrm{O}\right.$ or ${ }^{34} \mathrm{~S} /{ }^{32} \mathrm{~S}$ ) in The Trivedi Effect ${ }^{\circledR}$ - Consciousness Energy Healing Treated sulfamethoxazole compared to the control sample.

\section{Materials and Methods}

\section{Chemicals and Reagents}

Sulfamethoxazole was purchased from Sigma Aldrich, USA. Other chemicals used during the experiments were of analytical grade available in India.

\section{Consciousness Energy Healing Treatment Strategies}

The sulfamethoxazole powder was the test sample divided into two parts. One part of sulfamethoxazole powder sample was considered as a control sample (no Biofield Energy Treatment was provided). However, the other part of sulfamethoxazole was treated with The Trivedi Effect ${ }^{\circledR}$ - Consciousness Energy Healing Treatment remotely under standard laboratory conditions for 3 minutes and known as The Trivedi Effect ${ }^{\circledR}$ Treated or Biofield Energy Treated sulfamethoxazole sample. The Biofield Energy Treatment was provided through the healer's unique energy transmission process by the renowned Biofield Energy Healer, Alice Branton, USA, to the test sample. Further, the control sample was treated with "sham" healer for comparison purpose. The sham healer did not have any knowledge about the Biofield Energy Treatment. After that, the Biofield Energy Treated and untreated sulfamethoxazole samples were kept in sealed conditions and characterized using LC-MS and GC-MS, analytical techniques.

\section{Characterization}

\section{Liquid chromatography-mass spectrometry (LC-MS) analysis and Calculation of Isotopic Abundance Ratio}

The LC-MS analysis of the control and Biofield Energy Treated sulfamethoxazole was carried out with the help of LCMS ThermoFisher Scientific, the USA equipped with an ion trap detector connected with a triple-stage quadrupole mass spectrometer. The column used here was a reversed phase Thermo Scientific Synchronis C18 (Length-250 mm X ID $4.6 \mathrm{~mm}$ $\mathrm{X} 5$ micron), maintained at $25{ }^{\circ} \mathrm{C}$. The diluent used for the sample preparation was methanol. $5 \mu \mathrm{L}$ of sulfamethoxazole solution was injected, and the analyte was eluted using acetonitrile + $0.1 \%$ formic acid (75:25) pumped at a constant flow rate of $0.5 \mathrm{~mL} / \mathrm{min}$. Chromatographic separation was achieved using gradient condition and the total run time was 10 min. Peaks were monitored at $254 \mathrm{~nm}$ using the PDA detector. The mass spectrometric analysis was performed under -ve ESI mode. The total ion chromatogram, peak area\% and mass spectrum of the individual peak which was appeared in LC along with the full scan $(\mathrm{m} / \mathrm{z}$ 50-600) were recorded. The total ion chromatogram and mass spectrum of the individual peak (appeared in LC-MS) were recorded. The natural abundance of each isotope $(\mathrm{C}, \mathrm{H}, \mathrm{N}, \mathrm{O}$, and $\mathrm{S})$ can be predicted from the comparison of the height of the isotope 
peak with respect to the base peak. The values of the natural isotopic abundance of the common elements are obtained from the literature [30,32-34]. The LC-MS based isotopic abundance ratios $\left(\mathrm{P}_{\mathrm{M}+1} / \mathrm{P}_{\mathrm{M}}\right)$ for the control and Biofield Energy Treated sulfamethoxazole was calculated.

Percentage (\%) change in isotopic abundance ratio = $\left.\left[\left(\mathrm{IAR}_{\text {Treated }}-\mathrm{IAR}_{\text {Control }}\right) / \mathrm{IAR}_{\text {Control }}\right] \times \mathrm{100}\right]$

Where $\mathrm{IAR}_{\text {Treated }}=$ isotopic abundance ratio in the treated sample and $\mathrm{IAR}_{\text {Control }}=$ isotopic abundance ratio in the control sample.

\section{Gas chromatography-mass spectrometry (GC-MS) analysis}

GC-MS of the control and Biofield Energy Treated sample of sulfamethoxazole were analyzed with the help of Perkin Elmer Gas chromatograph equipped with a PE-5MS (30M x 250 micros x 0.250 microns) capillary column and coupled to a single quadrupole mass detector was operated with electron impact (EI) ionization in positive mode. Oven temperature was programmed from $75{ }^{\circ} \mathrm{C}$ (5 min hold) to $280{ }^{\circ} \mathrm{C}$ (14.5 min hold) @ $10{ }^{\circ} \mathrm{C} / \mathrm{min}$ (total run time $40 \mathrm{~min}$ ). The sample was prepared taking $60 \mathrm{mg}$ of the sulfamethoxazole in $4 \mathrm{ml}$ acetonitrile and water (1:1) as a diluent. Mass spectra were scanned from $m / z 20$ to 400. The identification of analyte was done by GC retention times and by a comparison of the mass spectra of samples. The GC-MS based isotopic abundance ratios $\left(\mathrm{P}_{\mathrm{M}+1} / \mathrm{P}_{\mathrm{M}}\right.$ and $\left.\mathrm{P}_{\mathrm{M}+2} / \mathrm{P}_{\mathrm{M}}\right)$ for the control and Biofield Energy Treated sulfamethoxazole was calculated.

Percentage (\%) change in isotopic abundance ratio = $\left.\left[\left(\mathrm{IAR}_{\text {Treated }}-\mathrm{IAR}_{\text {Control }}\right) / \mathrm{IAR}_{\text {Control }}\right] \times \mathrm{x} 100\right]$

Where $\mathrm{IAR}_{\text {Treated }}=$ isotopic abundance ratio in the treated sample and $\mathrm{IAR}_{\text {Control }}=$ isotopic abundance ratio in the control sample.

\section{Results and Discussion}

\section{Liquid chromatography-mass spectrometry (LC-MS)}

The chromatograms and mass spectra of both the samples of sulfamethoxazole are shown in the (Figure 1\&2), respectively. The chromatograms of sulfamethoxazole showed the single major chromatographic peak at the retention time $\left(\mathrm{R}_{\mathrm{t}}\right)$ of 2.5 minutes in case of both the samples (Figure 1). This indicated that the polarity of both the samples was same. ESI-MS of sulfamethoxazole was detected with the molecular mass peak [M-H]- at $m / z 252$ in the MS spectrum in negative ion mode [35]. The mass spectra of both the samples of sulfamethoxazole (Figure 2) exhibited the mass of the deprotonated molecular ion peak at $\mathrm{m} / \mathrm{z} 252$ [M-H]- (calculated for $\mathrm{C}_{10} \mathrm{H}_{10} \mathrm{~N}_{3} \mathrm{O}_{3} \mathrm{~S}, 252.04$ ) along with other fragmentation peaks in the control sample and Biofield Energy Treated sample (Figure 3).

The LC-MS spectra of both the control and Biofield Energy Treated sulfamethoxazole showed the mass of the molecular ion peak at $m / z 252[\mathrm{M}-\mathrm{H}]^{-}$(calculated for $\mathrm{C}_{10} \mathrm{H}_{10} \mathrm{~N}_{3} \mathrm{O}_{3} \mathrm{~S}$, 252.04) with relative intensity of $100 \%$. The theoretical calculation of $\mathrm{P}_{\mathrm{M}+1}$ for sulfamethoxazole was presented as below:

$P\left({ }^{13} \mathrm{C}\right)=[(10 \times 1.1 \%) \times 100 \%$ (the actual size of the M- peak) $]$ $/ 100 \%=11 \%$

$$
\begin{aligned}
& P\left({ }^{2} \mathrm{H}\right)=[(10 \times 0.015 \%) \times 100 \%] / 100 \%=0.15 \% \\
& P\left({ }^{15} \mathrm{~N}\right)=[(3 \times 0.4 \%) \times 100 \%] / 100 \%=1.2 \% \\
& P\left({ }^{17} \mathrm{O}\right)=[(3 \times 0.04 \%) \times 100 \%] / 100 \%=0.12 \% \\
& P\left({ }^{33}\right)=[(1 \times 0.75 \%) \times 100 \%] / 100 \%=0.75 \%
\end{aligned}
$$

$\mathrm{P}_{\mathrm{M}+1}$, i.e. ${ }^{13} \mathrm{C},{ }^{2} \mathrm{H},{ }^{15} \mathrm{~N},{ }^{17} \mathrm{O}$ and ${ }^{33} \mathrm{~S}$ contributions from $\left(\mathrm{C}_{10} \mathrm{H}_{10} \mathrm{~N}_{3} \mathrm{O}_{3} \mathrm{~S}\right)^{-}$to $\mathrm{m} / \mathrm{z} 253=13.22 \%$

From the above calculation, it has been found that ${ }^{13} \mathrm{C},{ }^{15} \mathrm{~N}$, and ${ }^{33} \mathrm{~S}$ have major contribution to $\mathrm{m} / \mathrm{z} 253$.

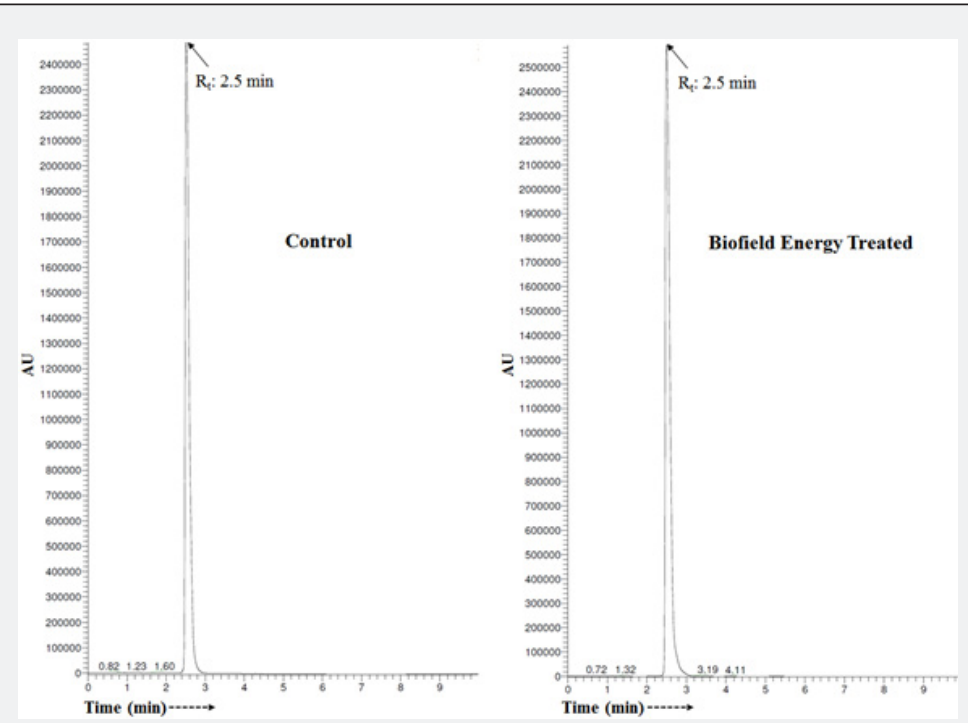

Figure 1: Liquid chromatograms of the control and Biofield Energy Treated sulfamethoxazole. 

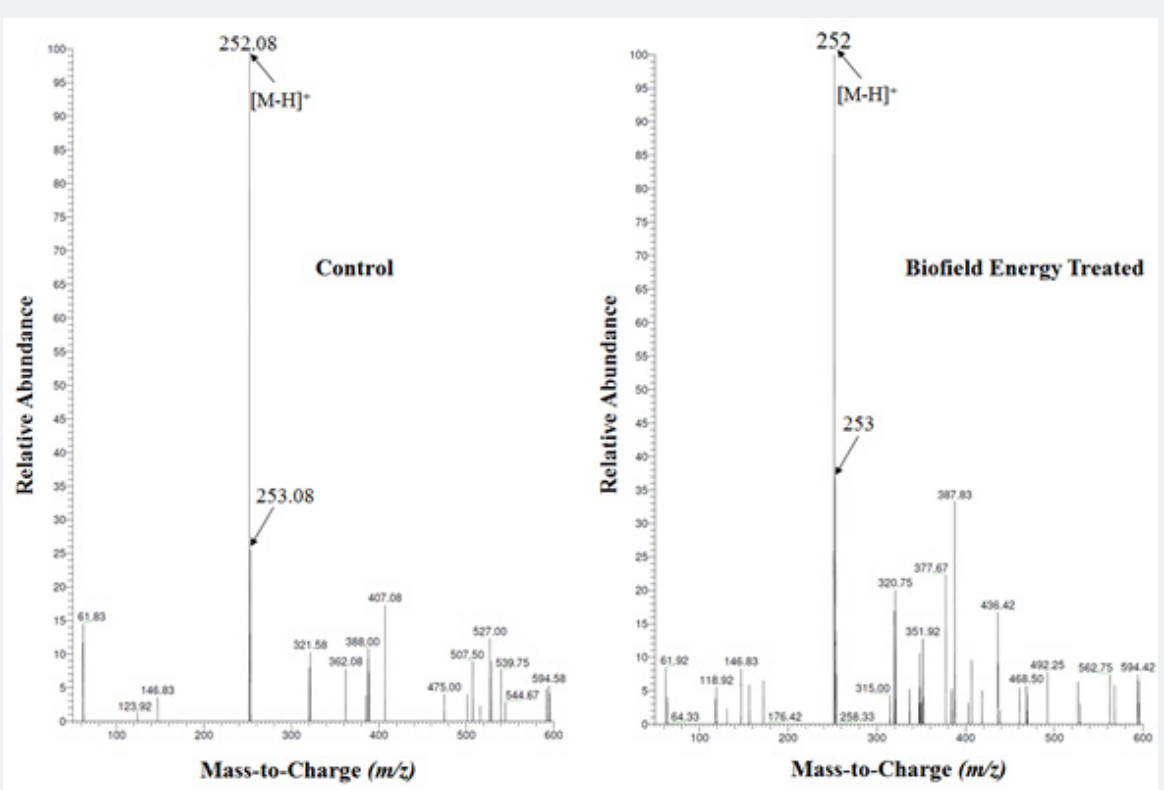

Figure 2: Mass spectra of the control and Biofield Energy Treated sulfamethoxazole at $R_{t} 2.5$ minutes.<smiles>Cc1cc(NS(=O)(=O)c2ccc(N)cc2)no1</smiles>

Figure 3: Proposed fragmentation pattern of sulfamethoxazole.

The LC-MS based isotopic abundance ratio analysis $\mathrm{P}_{\mathrm{M}}$ and $\mathrm{P}_{\mathrm{M}+1}$ for sulfamethoxazole near $m / z 252$ and 253, respectively of the control and Biofield Energy Treated samples, which were obtained from the observed relative peak intensities of $\left[\mathrm{M}^{+}\right]$and $\left[(\mathrm{M}+1)^{+}\right]$peaks, respectively in the ESI-MS spectra (Table 1$)$. The percentage change of the isotopic abundance ratio $(\mathrm{PM}+1 / \mathrm{PM})$ in the Biofield Energy Treated sulfamethoxazole was significantly increased by $44.67 \%$ compared with the control sample (Table 1). Therefore, it was concluded that the ${ }^{13} \mathrm{C},{ }^{2} \mathrm{H},{ }^{15} \mathrm{~N},{ }^{17} \mathrm{O}$, and ${ }^{33} \mathrm{~S}$ contributions from $\left(\mathrm{C}_{10} \mathrm{H}_{10} \mathrm{~N}_{3} \mathrm{O}_{3} \mathrm{~S}\right)^{-}$to $\mathrm{m} / z 253$ in the Biofield Energy Treated sample were significantly increased compared to the control sample.

Table 1: LC-MS based isotopic abundance analysis results in Biofield Energy Treated sulfamethoxazole compared to the control sample.

\begin{tabular}{|c|c|c|}
\hline Parameter & Control sample & Biofield Energy Treated sample \\
\hline $\mathrm{P}_{\mathrm{M}}$ at $m / z 252(\%)$ & 100 & 100 \\
\hline $\mathrm{P}_{\mathrm{M}+1}$ at $m / z 253(\%)$ & 25.52 & 36.92 \\
\hline $\mathrm{P}_{\mathrm{M}+1} / \mathrm{P}_{\mathrm{M}}$ & 0.26 & 0.37 \\
\hline $\begin{array}{l}\text { \% Change of isotopic abundance ratio }\left(\mathrm{P}_{\mathrm{M}+1} / \mathrm{P}_{\mathrm{M}}\right) \text { with respect to the control } \\
\text { sample }\end{array}$ & & 44.67 \\
\hline
\end{tabular}

PM: the relative peak intensity of the parent molecular ion $\left[\mathrm{M}^{+}\right] ; \mathrm{P}_{\mathrm{M}+1}$ : the relative peak intensity of the isotopic molecular ion $\left[(\mathrm{M}+1)^{+}\right], \mathrm{M}:$ mass of the parent molecule. 
Gas chromatography-mass spectrometry (GC-MS) analysis

The control and Biofield Energy Treated sulfamethoxazole showed the presence of a sharp chromatographic peak at the retention time of $16.91 \mathrm{~min}$ in the GC-MS chromatograms (Figure 4 \& 5). The peak area\% of the Biofield Energy Treated sample was significantly increased by $80.3 \%$ compared to the control sample. This indicated that the solubility of the Biofield Energy Treated sulfamethoxazole was significantly increased compared to the control sample. The peak near the $\mathrm{R}_{\mathrm{t}}$ of $13 \mathrm{~min}$ in both the chromatograms was due to the sulphanilamide present in the sample. The parent molecular ion peak of sulfamethoxazole at $\mathrm{m} / \mathrm{z} 253[\mathrm{M}]^{+}$(calculated for $\mathrm{C}_{10} \mathrm{H}_{11} \mathrm{~N}_{3} \mathrm{O}_{3} \mathrm{~S}^{+}, 253.05$ ) in the control sample and Biofield Energy Treated sample, along with the lower mass fragment ion peaks near $m / z 156$ and 92 (Figures 4 \& 5) which were proposed corresponded to the molecular formula $\mathrm{C}_{6} \mathrm{H}_{6} \mathrm{NO}_{2} \mathrm{~S}^{+}$and $\mathrm{C}_{6} \mathrm{H}_{6} \mathrm{~N}^{+}$, respectively (Figure 3). The isotopic abundance ratio depends upon the mass peak intensities of the particular compounds, which was well supported by the LC-MS based isotopic abundance ratio analysis.

The GC-MS spectra of both the control and Biofield Energy Treated sulfamethoxazole showed the mass of the molecular ion peak $[\mathrm{M}]^{+}$at $m / z 253[\mathrm{M}]^{+}$(calculated for $\mathrm{C}_{10} \mathrm{H}_{11} \mathrm{~N}_{3} \mathrm{O}_{3} \mathrm{~S}^{+}, 253.05$ ).
The theoretical calculation of $\mathrm{P}_{\mathrm{M}+1}$ and $\mathrm{P}_{\mathrm{M}+2}$ for sulfamethoxazole was presented as below:

$\mathrm{P}\left({ }^{13} \mathrm{C}\right)=[(10 \times 1.1 \%) \times 2.36 \%$ (the actual size of the $\mathrm{M}+$ peak $\left.)\right]$ $/ 100 \%=0.26 \%$

$\mathrm{P}\left({ }^{2} \mathrm{H}\right)=[(11 \times 0.015 \%) \times 2.36 \%] / 100 \%=0.004 \%$

$P\left({ }^{15} \mathrm{~N}\right)=[(3 \times 0.4 \%) \times 2.36 \%] / 100 \%=0.03 \%$

$\mathrm{P}\left({ }^{17} \mathrm{O}\right)=[(3 \times 0.04 \%) \times 2.36 \%] / 100 \%=0.003 \%$

$P\left({ }^{33} S\right)=[(1 \times 0.75 \%) \times 2.36 \%] / 100 \%=0.02 \%$

$\mathrm{P}_{\mathrm{M}+1}$, i.e. ${ }^{13} \mathrm{C},{ }^{2} \mathrm{H},{ }^{15} \mathrm{~N},{ }^{17} \mathrm{O}$, and ${ }^{33} \mathrm{~S}$ contributions from $\left(\mathrm{C}_{10} \mathrm{H}_{11} \mathrm{~N}_{3} \mathrm{O}_{3} \mathrm{~S}\right)^{+}$to $\mathrm{m} / z 254=0.32 \%$

Similarly,

$P\left({ }^{18} \mathrm{O}\right)=[(3 \times 0.2 \%) \times 2.36 \%] / 100 \%=0.014 \%$

$\mathrm{P}\left({ }^{34} \mathrm{~S}\right)=[(1 \times 4.21 \%) \times 2.36 \%] / 100 \%=0.1 \%$

$\mathrm{P}_{\mathrm{M}+2}$, i.e. ${ }^{34} \mathrm{~S}$ contributions from $\left(\mathrm{C}_{10} \mathrm{H}_{11} \mathrm{~N}_{3} \mathrm{O}_{3} \mathrm{~S}\right)^{+}$to $\mathrm{m} / z 255=$ $0.114 \%$

From the above calculation, it has been found that ${ }^{13} \mathrm{C},{ }^{15} \mathrm{~N},{ }^{33} \mathrm{~S}$, and ${ }^{34} \mathrm{~S}$ have major contribution to $\mathrm{m} / \mathrm{z} 254$ and 255 .

f45

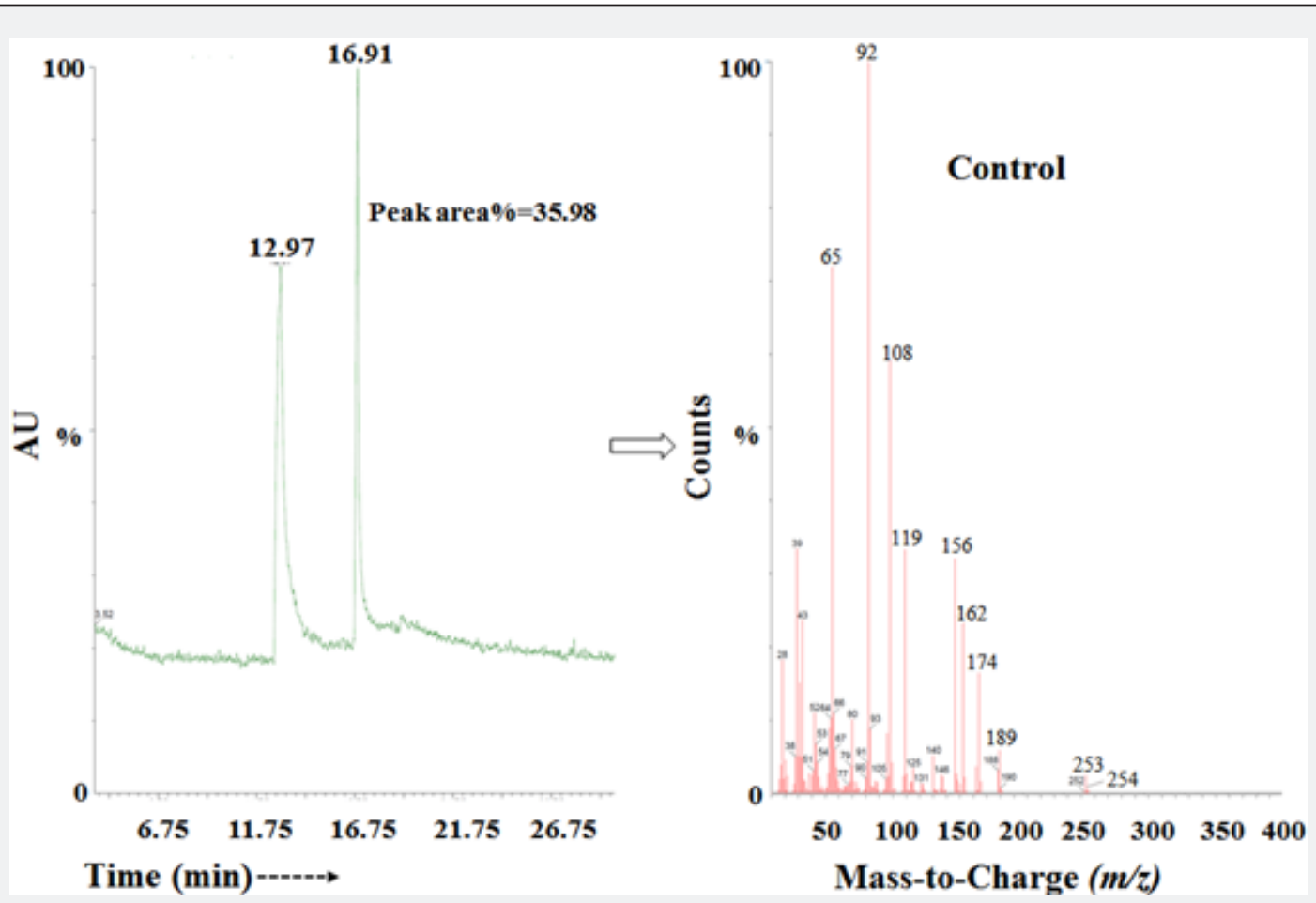

Figure 4: The GC-MS chromatogram and mass spectra of the control sulfamethoxazole.

The GC-MS based isotopic abundance ratio analysis of the Biofield Energy Treated samples were calculated compared to the control sample. $\mathrm{P}_{\mathrm{M}}, \mathrm{P}_{\mathrm{M}+1}$, and $\mathrm{P}_{\mathrm{M}+2}$ for sulfamethoxazole near $\mathrm{m} / \mathrm{z}$ 253,254 , and 255, respectively of the control and Biofield Energy
Treated samples, which were obtained from the observed relative peak intensities of $\left[\mathrm{M}^{+}\right],\left[(\mathrm{M}+1)^{+}\right]$, and $\left[(\mathrm{M}+2)^{+}\right]$peaks, respectively in the mass spectra and are presented in Table 2 . The isotopic abundance ratio of $\mathrm{P}_{\mathrm{M}+1} / \mathrm{P}_{\mathrm{M}}$ and of $\mathrm{P}_{\mathrm{M}+2} / \mathrm{P}_{\mathrm{M}}$ in the Biofield Energy 
Treated sulfamethoxazole was significantly increased by $24.13 \%$ and $90.53 \%$, respectively compared with the control sample (Table 2). Hence, ${ }^{13} \mathrm{C},{ }^{2} \mathrm{H},{ }^{15} \mathrm{~N},{ }^{17} \mathrm{O},{ }^{18} \mathrm{O},{ }^{33} \mathrm{~S}$, and ${ }^{34} \mathrm{~S}$ contributions from $\left(\mathrm{C}_{10} \mathrm{H}_{11} \mathrm{~N}_{3} \mathrm{O}_{3} \mathrm{~S}\right)^{+}$to $\mathrm{m} / \mathrm{z} 254$ and 255 in the Biofield Energy Treated sample were significantly increased compared with the control sample.

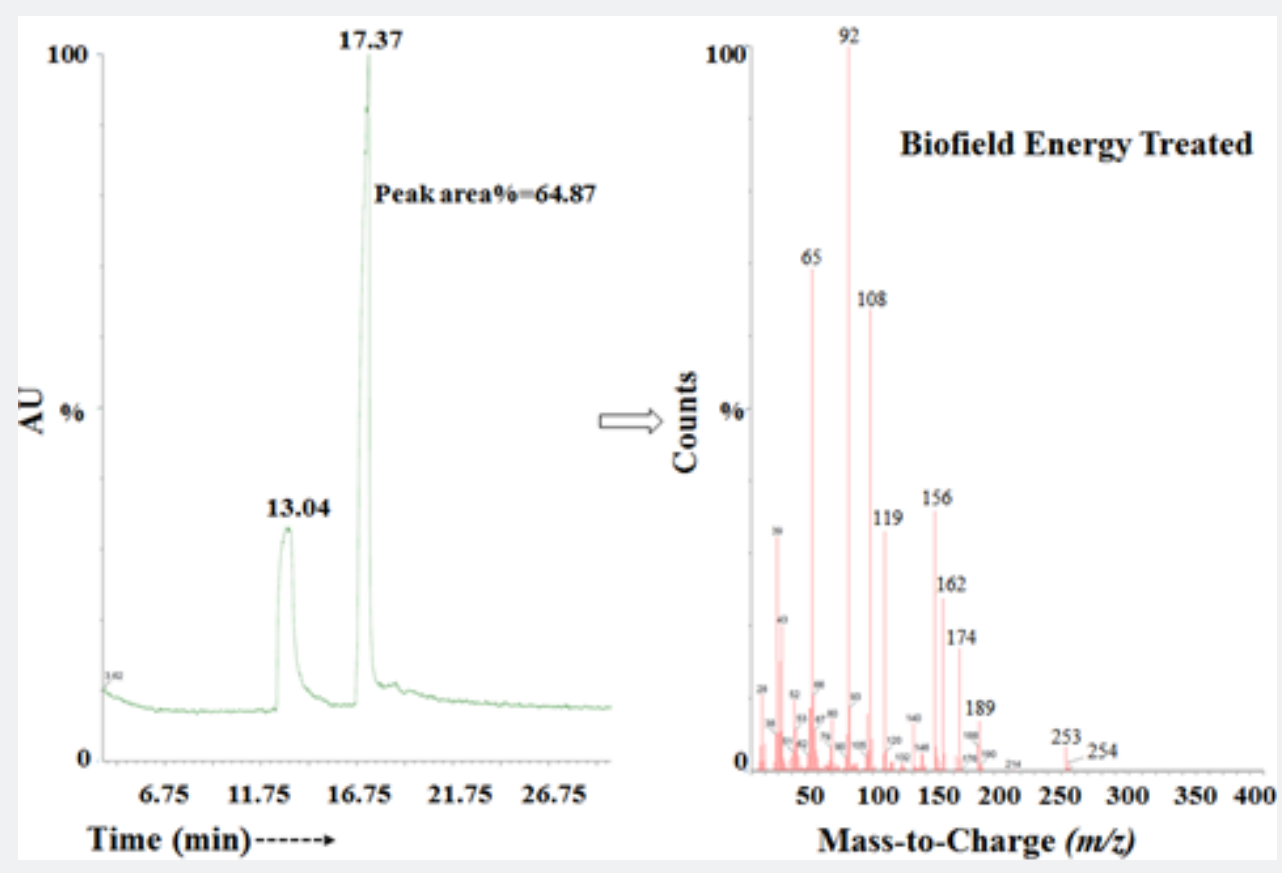

Figure 5: The GC-MS chromatogram and mass spectra of the Biofield Energy Treated sulfamethoxazole.

Table 2: GC-MS based isotopic abundance analysis results of Biofield Energy Treated sulfamethoxazole compared to the control samples.

\begin{tabular}{|c|c|c|}
\hline Parameter & Control sample & Biofield Energy Treated sample \\
\hline $\mathrm{P}_{\mathrm{M}}$ at $m / z 253(\%)$ & 2.36 & 3.27 \\
\hline $\mathrm{P}_{\mathrm{M}+1}$ at $m / z 254(\%)$ & 0.25 & 0.43 \\
\hline $\mathrm{P}_{\mathrm{M}+1} / \mathrm{P}_{\mathrm{M}}$ & 0.11 & 0.13 \\
\hline $\begin{array}{c}\% \text { Change of isotopic abundance ratio }\left(\mathrm{P}_{\mathrm{M}+1} / \mathrm{P}_{\mathrm{M}}\right) \text { with respect to the } \\
\text { control sample }\end{array}$ & & 24.13 \\
\hline $\mathrm{P}_{\mathrm{M}+2}$ at $m / z 255(\%)$ & 0.5 & 1.32 \\
\hline $\mathrm{P}_{\mathrm{M}+2} / \mathrm{P}_{\mathrm{M}}$ & 0.21 & 0.4 \\
\hline $\begin{array}{c}\% \text { Change of isotopic abundance ratio }\left(\mathrm{P}_{\mathrm{M}+1} / \mathrm{P}_{\mathrm{M}}\right) \text { with respect to the } \\
\text { control sample }\end{array}$ & & 90.53 \\
\hline
\end{tabular}

PM: the relative peak intensity of the parent molecular ion $\left[\mathrm{M}^{+}\right] ; \mathrm{P}_{\mathrm{M}+1}:$ the relative peak intensity of the isotopic molecular ion $\left[(\mathrm{M}+1)^{+}\right] ; \mathrm{P}_{\mathrm{M}+2}:$ the relative peak intensity of the isotopic molecular ion $\left[(\mathrm{M}+2)^{+}\right]$; $\mathrm{M}$ : mass of the parent molecule.

LC-MS and GC-MS study confirmed the structure of the sample as sulfamethoxazole. The isotopic abundance ratios of $\mathrm{P}_{\mathrm{M}+1} / \mathrm{P}_{\mathrm{M}}\left({ }^{2} \mathrm{H} /{ }^{1} \mathrm{H}\right.$ or ${ }^{13} \mathrm{C} /{ }^{12} \mathrm{C}$ or ${ }^{15} \mathrm{~N} /{ }^{14} \mathrm{~N}$ or ${ }^{17} \mathrm{O} /{ }^{16} \mathrm{O}$ or $\left.{ }^{33} \mathrm{~S} /{ }^{32} \mathrm{~S}\right)$ and $\mathrm{P}_{\mathrm{M}+2} / \mathrm{P}_{\mathrm{M}}\left({ }^{18} \mathrm{O} /{ }^{16} \mathrm{O}\right.$ or $\left.{ }^{34} \mathrm{~S} /{ }^{32} \mathrm{~S}\right)$ in the Biofield Energy Treated sulfamethoxazole were significantly altered compared to the control sample. According to science, the neutrinos change identities which are only possible if the neutrinos possess mass and have the ability to interchange their phase from one phase to another internally. Therefore, the neutrinos have the ability to interact with protons and neutrons in the nucleus, which indicated a close relation between neutrino and the isotope formation $[11,30,31]$. The altered isotopic composition in molecular level of The Trivedi Effect ${ }^{\circledR}$-Consciousness Energy Healing Treated sulfamethoxazole might have altered the neutron to proton ratio in the nucleus. It can be hypothesized that the changes in isotopic abundance could be due to changes in nuclei possibly through the interference of neutrino particles via The Trivedi Effect $^{\circledR}$ - Consciousness Energy Healing Treatment. The overall 
results concluded that The Trivedi Effect ${ }^{\circledR}$-Consciousness Energy Healing Treatment might create a new form of sulfamethoxazole which would show better solubility, dissolution, absorption and bioavailability compared with the untreated sample. The Trivedi Effect $^{\circledR}$ Treated sulfamethoxazole would be more suitable for the prevention and treatment of various diseases such as urinary tract infections, ear infections, traveler's diarrhea, shigellosis, bronchitis, and Pneumocystis jiroveci pneumonia, etc.

\section{Conclusion}

The Trivedi Effect ${ }^{\circledR}$-Consciousness Energy Healing Treatment showed the significant impact on the isotopic abundance ratios and mass peak intensities of sulfamethoxazole. The LC-MS spectra of both the control and Biofield Energy Treated samples at retention time $\left(R_{t}\right) 2.5$ minutes exhibited the mass of the deprotonated molecular ion peak at $m / z 252[\mathrm{M}-\mathrm{H}]^{-}$(calculated for $\mathrm{C}_{10} \mathrm{H}_{10} \mathrm{~N}_{3} \mathrm{O}_{3} \mathrm{~S}$, 252.04) in the -ve ion mode. The LC-MS based isotopic abundance ratio of $\mathrm{P}_{\mathrm{M}+1} / \mathrm{P}_{\mathrm{M}}$ in the Biofield Energy Treated sulfamethoxazole was significantly increased by $44.67 \%$ compared with the control sample. Thus, ${ }^{13} \mathrm{C},{ }^{2} \mathrm{H},{ }^{15} \mathrm{~N},{ }^{17} \mathrm{O}$, and ${ }^{33} \mathrm{~S}$ contributions from $\left(\mathrm{C}_{10} \mathrm{H}_{10} \mathrm{~N}_{3} \mathrm{O}_{3} \mathrm{~S}\right)^{-}$to $m / z 253$ in the Biofield Energy Treated sample were significantly increased compared with the control sample. The control and Biofield Energy Treated sulfamethoxazole showed the presence of chromatographic peak at the retention time of $16.91 \mathrm{~min}$ in the GC-MS chromatograms. The peak area\% of the Biofield Energy Treated sample was significantly increased by $80.3 \%$ compared to the control sample.

The GC-MS based isotopic abundance ratio of $\mathrm{P}_{\mathrm{M}+1} / \mathrm{P}_{\mathrm{M}}$ and of $\mathrm{P}_{\mathrm{M}+2} / \mathrm{P}_{\mathrm{M}}$ in the Biofield Energy Treated sulfamethoxazole was significantly increased by $24.13 \%$ and $90.53 \%$, respectively compared with the control sample. Hence, ${ }^{13} \mathrm{C},{ }^{2} \mathrm{H},{ }^{15} \mathrm{~N},{ }^{17} \mathrm{O},{ }^{18} \mathrm{O},{ }^{33} \mathrm{~S}$ and ${ }^{34} \mathrm{~S}$ contributions from $\left(\mathrm{C}_{10} \mathrm{H}_{10} \mathrm{~N}_{3} \mathrm{O}_{3} \mathrm{~S}\right)^{+}$to $\mathrm{m} / z 254$ and 255 in the Biofield Energy Treated sample were significantly increased compared with the control sample. The isotopic abundance ratios of $\mathrm{P}_{\mathrm{M}+1} / \mathrm{P}_{\mathrm{M}}\left({ }^{2} \mathrm{H} /{ }^{1} \mathrm{H}\right.$ or ${ }^{13} \mathrm{C} /{ }^{12} \mathrm{C}$ or ${ }^{15} \mathrm{~N} /{ }^{14} \mathrm{~N}$ or ${ }^{17} \mathrm{O} /{ }^{16} \mathrm{O}$ or $\left.{ }^{33} \mathrm{~S} /{ }^{32} \mathrm{~S}\right)$ and $\mathrm{P}_{\mathrm{M}+2} / \mathrm{P}_{\mathrm{M}}\left({ }^{18} \mathrm{O} /{ }^{16} \mathrm{O}\right.$ or $\left.{ }^{34} \mathrm{~S} /{ }^{32} \mathrm{~S}\right)$ in the Biofield Energy Treated sulfamethoxazole were significantly altered compared to the control sample. It can be assumed that the changes in isotopic abundance and mass peak intensities could be due to changes in nuclei possibly through the interference of neutrino particles via The Trivedi Effect ${ }^{\circledR}$-Consciousness Energy Healing Treatment. The new form of sulfamethoxazole would be better designing novel pharmaceutical formulations that might offer better solubility, dissolution, absorption, bioavailability and therapeutic response against urinary tract infections, ear infections, tuberculosis, traveler's diarrhea, shigellosis, bronchitis, and Pneumocystis jiroveci pneumonia, etc.

\section{Acknowledgements}

The authors are grateful to Sophisticated Instrumentation Centre for Applied Research \& Testing (SICART) India, Trivedi Science, Trivedi Global, Inc., Trivedi Testimonials, and Trivedi Master Wellness for their assistance and support during this work.

\section{References}

1. Zander J, Besier S, Ackermann H, Wichelhaus TA (2010) Synergistic antimicrobial activities of folic acid antagonists and nucleoside analogs. Antimicrob Agents Chemother 54(3): 1226-1231.

2. Neu HC, Gootz TD (1996) Antimicrobial Chemotherapy. In: Baron S (ed.), Medical Microbiology. $4^{\text {th }}$ edn University of Texas Medical Branch at Galveston, Galveston TX, USA.

3. Brunton L, Chabner BA, Knollman B (2011) Goodman and Gilman's The pharmacological Basis of Therapeautics. $12^{\text {th }}$ edn, The McGrawHill Companies, Inc., USA.

4. Close SJ, McBurney CR, Garvin CG, Chen DC, Martin SJ (2002) Trimethoprimsulfamethoxazole activity and pharmacodynamics against glycopeptideintermediate Staphylococcus aureus. Pharmacotherapy 22(8): 983-989.

5. Mulla SI, Hu A, Sun Q Li J, Suanon F, Ashfaq M, Yu CP (2018) Biodegradation of sulfamethoxazole in bacteria from three different origins. J Environ Manage. 206: 93-102.

6. Savjani KT, Gajjar AK, Savjani JK (2012) Drug Solubility: Importance and Enhancement Techniques. ISRN Pharmaceutics, 195727.

7. Khadka P, Ro J, Kim H, Kim I, Kim JT, et al. (2014) Pharmaceutical particle technologies: An approach to improve drug solubility, dissolution and bioavailability. Asian J Pharm 9(6): 304-316.

8. Trivedi MK, Branton A, Trivedi D, Nayak G, Afaganis AE, et al. (2017) An Impact of energy of consciousness (The Trivedi Effect ${ }^{\circledR}$ ) on the physicochemical, thermal, structural, and behavioral properties of magnesium gluconate. Biomedical Sciences 3(2): 42-54.

9. Trivedi MK, Branton A, Trivedi D, Nayak G, Lee AC, et al. (2016) Impact of biofield energy treated herbomineral formulation (The Trivedi Effect ${ }^{\circledR}$ ) on mouse dendritic and splenocyte cells for modulation of pro-inflammatory cytokines. International Journal of Immunology 4(5): 35-45.

10. Trivedi MK, Branton A, Trivedi D, Nayak G, Wellborn BD, et al. (2017) Effect of the energy of consciousness (The Trivedi Effect ${ }^{\circledR}$ ) on the structural properties and isotopic abundance ratio of magnesium gluconate using LC-MS and NMR spectroscopy. Advances in Biochemistry 5(1): 7-15.

11. Trivedi MK, Mohan TRR (2016) Biofield energy signals, energy transmission and neutrinos. American Journal of Modern Physics 5(6): 172-176.

12. Rubik B (2002) The biofield hypothesis: Its biophysical basis and role in medicine. J Altern Complement Med 8(6): 703-717.

13. Nemeth L (2008) Energy and biofield therapies in practice. Beginnings 28(3): 4-5.

14. Rubik B, Muehsam D, Hammerschlag R, Jain S (2015) Biofield science and healing: history, terminology, and concepts. Glob Adv Health Med 4: 8-14

15. Koithan M (2009) Introducing complementary and alternative therapies. J Nurse Pract 5(1): 18-20.

16. Barnes PM, Bloom B, Nahin RL (2008) Complementary and alternative medicine use among adults and children: United States, 2007. Natl Health Stat Report 12: 1-23.

17. Trivedi MK, Branton A, Trivedi D, Nayak G, Sethi KK, et al. (2016) Gas chromatography-mass spectrometry based isotopic abundance ratio analysis of biofield energy treated methyl-2-napthylether (Nerolin). American Journal of Physical Chemistry 5: 80-86.

18. Trivedi MK, Branton A, Trivedi D, Nayak G, Bairwa K, et al. (2015) Spectroscopic characterization of disodium hydrogen orthophosphate and sodium nitrate after biofield treatment. J Chromatogr Sep Tech 6(5): 282. 
19. Trivedi MK, Nayak G, Patil S, Tallapragada RM, Latiyal O (2015) Studies of the atomic and crystalline characteristics of ceramic oxide nano powders after bio field treatment. Ind Eng Manage 4: 161.

20. Trivedi MK, Nayak G, Patil S, Tallapragada RM, Latiyal O, et al. (2015) Effect of biofield energy treatment on physical and structural properties of calcium carbide and praseodymium oxide. International Journal of Materials Science and Applications 4: 390-395.

21. Trivedi MK, Branton A, Trivedi D, Nayak G, Gangwar M, et al. (2015) Agronomic characteristics, growth analysis, and yield response of biofield treated mustard, cowpea, horse gram, and groundnuts. International Journal of Genetics and Genomics. 3: 74-80.

22. Trivedi MK, Branton A, Trivedi D, Nayak G, Mondal SC, et al. (2015) Evaluation of plant growth, yield and yield attributes of biofield energy treated mustard (brassica juncea) and chick pea (Cicer arietinum) seeds. Agriculture, Forestry and Fisheries 4: 291-295.

23. Trivedi MK, Branton A, Trivedi D, Nayak G, Charan S, et al. (2015) Phenotyping and 16S rDNA analysis after biofield treatment on Citrobacter braakii: A urinary pathogen. J Clin Med Genom 3: 129.

24. Trivedi MK, Patil S, Shettigar H, Mondal SC, Jana S (2015) Evaluation of biofield modality on viral load of Hepatitis $\mathrm{B}$ and $\mathrm{C}$ viruses. J AntivirAntiretrovir 7: 083-088.

25. Branton A, Jana S (2017) The influence of energy of consciousness healing treatment on low bioavailable resveratrol in male Sprague Dawley rats. International Journal of Clinical and Developmental Anatomy 3(3): 9-15.

26. Branton A, Jana S (2017) The use of novel and unique biofield energy healing treatment for the improvement of poorly bioavailable compound, berberine in male Sprague Dawley rats. American Journa of Clinical and Experimental Medicine 5(4): 138-144.
27. Trivedi MK, Branton A, Trivedi D, Nayak G, Sethi KK, et al. (2016) Isotopic abundance ratio analysis of biofield energy treated indole using gas chromatography-mass spectrometry. Science Journal of Chemistry 4(4): 41-48.

28. Trivedi MK, Branton A, Trivedi D, Nayak G, Panda P, et al. (2016) Evaluation of the isotopic abundance ratio in biofield energy treated resorcinol using gas chromatography-mass spectrometry technique. Pharm Anal Acta 7: 481

29. Schellekens RC, Stellaard F, Woerdenbag HJ, Frijlink HW, Kosterink JG (2011) Applications of stable isotopes in clinical pharmacology. Br J Clin Pharmacol 72(6): 879-897.

30. Weisel CP, Park S, Pyo H, Mohan K, Witz G (2003) Use of stable isotopically labeled benzene to evaluate environmental exposures. J Expo Anal Environ Epidemiol 13(5): 393-402.

31. Muccio Z, Jackson GP (2009) Isotope ratio mass spectrometry. Analyst 134(2): 213-222.

32. Rosman KJR, Taylor PDP (1998) Isotopic compositions of the elements 1997 (Technical Report). Pure Appl Chem 70: 217-235.

33. Smith RM (2004) Understanding Mass Spectra: A Basic Approach, Second Edition, John Wiley \& Sons, Inc, USA.

34.Jürgen H (2004) Gross Mass Spectrometry: A Textbook (2 ${ }^{\text {nd }}$ Edn) Springer, Berlin, Germany.

35. Sanderson JP, Hollis FJ, Maggs JL, Clarke SE, Naisbitt DJ, Park BK (2008) Nonenzymatic formation of a novel hydroxylated sulfamethoxazole derivative in human liver microsomes: implications for bioanalysis of sulfamethoxazole metabolites. Drug Metab Dispos 36(12): 2424-2428.

Your next submission with Juniper Publishers will reach you the below assets

- Quality Editorial service

- Swift Peer Review

- Reprints availability

- E-prints Service

- Manuscript Podcast for convenient understanding

- Global attainment for your research

- Manuscript accessibility in different formats

(Pdf, E-pub, Full Text, Audio)

- Unceasing customer service

Track the below URL for one-step submission

https://juniperpublishers.com/online-submission.php 